\title{
The Scope of Definition of a Terrorist Act under Ethiopian Law: Appraisal of its Compatibility with Regional and International Counterterrorism Instruments
}

Wondwossen Demissie Kassa *

\begin{abstract}
While regional and international human rights institutions claim that the definition of a terrorist act under the Anti-terrorism Proclamation No. $652 / 2009$ is overly broad as a result of which citizens not involved in a genuinely terrorist act are prosecuted and jailed, the Ethiopian government defends the law pointing that it is borrowed from jurisdictions with advanced legal system and rule of law. This article is concerned with this debate and suggests how to deal with it. The article employs definitions under relevant regional and international counterterrorism legal instruments as standard to examine the scope of the domestic definition. With regard to some of its elements, the proclamation's definition is broader than the standard definitions; in other aspects it is narrower. The regional and international instruments simply indicate what states should proscribe as a terrorist act without further prohibiting them from including other conduct with in domestic definitions. As such, being broader per se does not render the definition incompatible with regional and international definitions. On areas where the definition is narrower, its strict application would mean non-prosecution or, in the event of prosecution, acquittal of persons who would have been treated as terrorist under regional and international law. This has a direct bearing on Ethiopia's counterterrorism obligation.
\end{abstract}

\section{Key words}

Definition of a Terrorist act, Ethiopian anti-terrorism proclamation, OAU Convention on the Prevention and Combating of Terrorism, Security Council Resolution 1373, International Convention for the Suppression of Financing of Terrorism.

DOI http://dx.doi.org/10.4314/mlr.v8i2.4

\footnotetext{
* LL.B, LL. M., PhD candidate at Flinders University Law School. Email: $<$ Wondwossen.kassa@flinders.edu.au>. I am grateful to the two anonymous reviewers for their scholarly insights and constructive comments.
} 


\section{Introduction}

International and regional legal instruments urge states to prevent the commission of a terrorist act through, inter alia, criminalization. Although some are sceptical about the need and motive for promulgation of the Ethiopian anti-terrorism Proclamation No. 652/2009 (hereafter the Proclamation) ${ }^{1}$ from a legal point of view, by criminalizing a terrorist act, Ethiopia discharges its responsibility under international law.

Article 3 of the Proclamation provides for a definition of a terrorist act. The definition establishes the threshold of a "terrorist act" from a legal perspective. This vital first step has been controversial ever since the law was presented in its draft form. ${ }^{2}$ While regional and international human rights institutions express concern on the broadness of definition of a terrorist act, officials of the Ethiopian government and some others defend it as being not broader than definitions in other jurisdictions.

This article deals with scope of definition of a terrorist act under the proclamation in the following order. The first section briefly outlines the controversy surrounding the scope of the definition and how the purported lack of universally applicable definition of a terrorist act could be a major obstacle to undertake a meaningful assessment on the scope of definition of a terrorist act in a domestic legislation. Furthermore, it examines the plausibility of the government's argument to justify the reach of the definition. Section 2 proposes two definitions of a terrorist act (one international and the other regional) that can be used as standard to evaluate the scope of the definition under the proclamation followed by analysis of their elements in Section 3. The fourth section discusses the definition of a terrorist act under the Proclamation. The discussion, not being intended to provide an in-depth analysis and interpretation of the definition ${ }^{3}$, is confined

\footnotetext{
${ }^{1}$ See: Ethiopian Political Parties Position on the Anti-Terrorism Law, parts 1-3.

Retrieved from: $<$ https://www.youtube.com/watch?v=urSqiLnYzQ0 ; https://www.youtube.com/watch?v=Nr76bQEtnlA ; http://www.ethiopian.tv/ethiopian-political-parties-position-on-the-anti-terrorismlaw-part-3/>.

${ }^{2}$ Human Rights watch (2009), An Analysis of Ethiopia's Draft Anti-Terrorism Law Updated, Retrieved from

$<$ http://www.hrw.org/sites/default/files/related_material/Ethiopia\%20CT\%20Law \%20Analysis\%20June\%202009_2.pdf >.

${ }^{3}$ For a brief analysis on how some parts of the definition could be applied broadly see: Hiruy Wube (2012), "Some Points on the Ethiopian Anti-Terrorism Law
} 
to the extent needed to evaluate the scope of the definition. Section 5 is the actual appraisal of the definition. It examines the definition vis-à-vis the proposed standard definitions, and reveals a mixture of narrowness and broadness therein. The section further examines the effect, on its validity, of the definition's deviation from the standards. The article winds up with a conclusion.

\section{Controversy on the scope of the definition and the problematic nature of judging it}

\subsection{The controversy}

Regional and international human rights institutions have expressed concern on the broadness of definition of a terrorist act. In its analysis of the proclamation, Human Rights Watch identifies what it considers as problematic areas of the legislation, ${ }^{4}$ of which one is its 'extremely broad' definition of a terrorist act. In its Comment on Ethiopia's Anti-Terrorism Proclamation, Article 19 identifies over-broadness of the definitional provision as particularly worrying. ${ }^{5}$ David Shinn and Thomas Ofcansky label the definition as broad. ${ }^{6}$ Similarly, Hiruy points out some of the elements of the definition that would give it a wider reach. ${ }^{7}$ Many who do not agree with the conviction of journalists and opposition political party leaders under the proclamation attribute the conviction to the over-broadness of the definition. ${ }^{8}$

from Human Rights Perspective", Journal of Ethiopian Law, Vol, 25 No.2, pp. 43-46.

${ }^{4}$ Human Rights watch (2009), supra note 2, pp. 1, 4.

${ }^{5}$ Article 19 (2010), Comment on Anti-Terrorism Proclamation, 2009, of Ethiopia, pp. 3,4. Retrieved from:

$<$ http://www.article19.org/data/files/pdfs/analysis/ethiopia-comment-on-antiterrorism-proclamation-2009.pdf $>$.

6 David H. Shinn, and Thomas P. Ofcansky (2013), Historical Dictionary of Ethiopia, (Lanham Maryland: Scarecrow press), p. 388.

${ }^{7}$ Hiruy Wube (2012), supra note 3, pp. 43-46.

8 In 2012 UN High Commissioner for Human Rights Navi Pillay, denouncing conviction and sentencing of journalists and opposition figures, said she is seriously alarmed about the current climate of intimidation against human rights defenders and journalists in Ethiopia, resulting from the use of "overly broad" laws on terrorism and civil society registration. United Nations Human Rights (2012), Climate of intimidation against rights defenders and journalists in Ethiopia. Retrieved from: 
In response to such criticism, government officials ${ }^{9}$ claim the language of the definition was simply pulled from antiterrorism legislation of democratic jurisdictions, such as the United Kingdom, Australia and Canada, thereby asserting that it is not broader than the definitions in the anti-terrorism legislation of these countries. Others ${ }^{10}$ follow a similar approach and evaluate the scope of the definition under the anti-terrorism proclamation in

$<\mathrm{http} / / /$ www.ohchr.org/en/NewsEvents/Pages/DisplayNews.aspx?NewsID=12365 \&LangID=E >; Patrick Griffith (2013), "Ethiopia's Anti-Terrorism Proclamation and the right to freedom of expression", freedom now, August 30. Retrieved from: $<$ http://www.freedom-now.org/news/ethiopias-anti-terrorism-proclamation-andthe-right-to-freedom-of-expression/>; Human Rights Council Working Group on Arbitrary Detention (2012), Opinions Adopted by the Working Group on Arbitrary Detention at its Sixty Fifth Session, 14-23 Nov, No. 62/2012 (The Federal Democratic Republic of Ethiopia), Retrieved from: <http://www.freedomnow.org/wp-content/uploads/2013/04/Eskinder-Nega-WGAD-Opinion.pdf>;

Human Rights Watch (2011), Ethiopia: Journalists Convicted Under Unfair Law, Deeply Flawed anti-terrorism Act should be revoked, retrieved from: $<$ http://www.hrw.org/news/2011/12/21/ethiopia-journalists-convicted-underunfair-law> ; Amnesty International (2012), Ethiopia: Conviction of government opponents a 'dark day' for freedom of expression, retrieved from: $<$ http://www.amnesty.org/en/news/ethiopia-conviction-government-opponentsdark-day-freedom-expression-2012-06-27>.

${ }^{9}$ During a discussion of the law in its draft form it was indicated that the definition part is directly copied from the anti-terrorism law of the United Kingdom.Federal Democratic Republic of Ethiopia, $3^{\text {rd }}$ House of Peoples Representatives $(2008 / 2009), 4^{\text {th }}$ year Adopted Proclamations, Public Discussions and Recommendations, Volume 7, p.116-117.The late Prime Minster Meles Zenawi indicated that the proclamation is copied word by word from the UK. Yemane

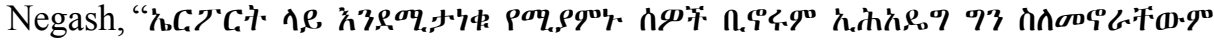

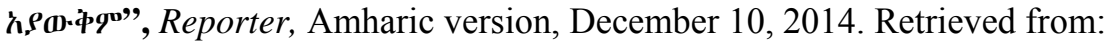
$<$ http://www.ethiopianreporter.com/index.php/politics/item/8182>. Also see: a program on Terrorism in Ethiopia hosted by Ethiopian Television and Radio Agency in 2013, part two, Available at:

<http://www.mereja.com/video/watch.php?vid=ecb2493b5>; Griffith (2013), supra note 8.

${ }^{10}$ SasahulehYalew, A Comparative Review of Ethiopian and Western AntiTerrorism Legislations. Retrieved from:

$<$ http://www.aigaforum.com/articles/Ethiopia-anti-terrorism.pdf $>$. A senior lawyer and a Federal High Court judge make this claim. Terrorism in Ethiopia, supra note 9 . 
light of definitions provided in the democratic jurisdictions to conclude that it is not broader, if not narrower.

\subsection{Plausibility of referencing to other jurisdictions}

Different standards are applied to examine the scope of definitions of a terrorist act in domestic anti-terrorism laws ${ }^{11}$ as a result of the commonly held view that international law does not provide a binding definition of terrorist act that states should comply with. Officials of the Ethiopian Government and others justify the reach of the definition in the proclamation claiming that it is copied from definitions in antiterrorism laws of other jurisdictions. How relevant and persuasive is this approach?

To start with, a quick comparison between the definition in the proclamation and in the foreign laws from which the definition is said to have been copied shows that the claim is misleading. Griffith, comparing the definition in the proclamation with that of the definition in the UK antiterrorism law, notes "while Ethiopia's Anti-Terror Proclamation borrows some key phrases, it is significantly more expansive - and vague - than the statutes it purports to mirror". 12 Griffith indicates "compared with UK's equivalent piece of legislation, the Ethiopian Anti-Terror Proclamation simply lifts an introductory paragraph while omitting the following seven sections that define and limit the law's scope". ${ }^{13}$ Furthermore, while the motive requirement in the definition of the UK anti-terrorism legislation has been amended, ${ }^{14}$ it forms part of the definition under the Ethiopian Antiterrorism Proclamation.

The Australian anti-terrorism law, one of the legislation said to have been used as a basis for the Ethiopian Anti-terrorism Proclamation, incorporates a sub-article which provides for an exception to "advocacy, protest, dissent or industrial action" not to be considered as terrorist acts if not intended to

11 Reuven Young (2006), "Defining Terrorism: The Evolution of Terrorism as a Legal Concept in International Law and Its Influence on Definitions in Domestic Legislation", Boston College International and Comparative Law Review, Vol. 29, issue 1; Keiran Hardy and George Williams (2011), 'What is "terrorism"? Assessing Domestic Legal Definitions' UCLA Journal of International Law \& Foreign Affairs, Vol. 16.

${ }^{12}$ Griffith (2013), supra note 8.

${ }^{13}$ Ibid.

${ }^{14}$ Counter-terrorism Act 2008 (UK), s 75(1); Roger Douglas (2010), Must terrorists act for a cause? The motivational requirement in definitions of terrorism in the United Kingdom, Canada, New Zealand and Australia, Commonwealth Law Bulletin, 36:2, 295-312, p. 299 DOI: 10.1080/03050718.2010.481400 
"cause serious harm that is physical harm to a person; or cause a person's death; or endanger the life of a person, other than the person taking in the action; or create a serious risk to the health or safety of the public or a section of the public". ${ }^{15}$ This political protest exception, which is commended as a safeguard for legitimate forms of political activities, ${ }^{16}$ is not part of the Ethiopian anti-terrorism proclamation.

Be the factual accuracy of the claim as it may, there are several reasons that would make the aptness of defending the scope of the definition by invoking its sources doubtful. First, the relevance of this approach to Ethiopia where reference to legislation or cases decided in other jurisdictions is not a recognized way of resolving a legal issue ${ }^{17}$, is minimal, if any, other than for legal scholarship purposes.

Second, the definitions embodied in the anti-terrorism legislation of jurisdictions that are invoked to have been used as basis for the definition in the proclamation have been condemned by international human rights bodies. For example, in 2005, the Human Rights Committee found that the definition of terrorism in the Canadian Anti-Terrorism Act 2001 was overly broad. ${ }^{18}$ The Committee found that the similar language in the Australian Anti-Terrorism Act (No. 2) 2005 violated international human rights norms and recommended its amendment. ${ }^{19}$

Thus, the definition in the proclamation being a reproduction of the definitions in the cited jurisdictions does not save the definition from being criticised as a broad one. Rather, by the government's own admission, the definition would be vulnerable to the same criticism as its sources have been subjected to, one of which is broadness. What is worse, the definition in the proclamation, as opposed to its claimed sources, is devoid of safeguards against misuse of the definition to suppress legitimate political activities.

${ }^{15}$ Criminal Code Act 1995 (Cth), s 100.1 (Austl); Jude McCulloch (2002-2003), "Counterterrorism Human Security and Globalization from Welfare to warfare State?"Current issues in criminal justice, vol. 14, p. 285.

16 Sec. Legislation Review Comm. (Austl.), Report of the Security Legislation Review Committee 57 (June 2006) in Hardy and Williams (2011), supra note 11, p. 135.

17 Article 78 (3) of the FDRE Constitution provides: "Judges shall exercise their functions in full independence and shall be directed solely by the law."

18 Concluding observations of the Human Rights Committee, Canada, UN Doc. $\mathrm{CCPR} / \mathrm{C} / \mathrm{CAN} / \mathrm{CO} / 5,2$ November 2005).

${ }^{19}$ Concluding observations of the Human Rights Committee, Australia, CCPR/C/AUS/CO/5/CRP/1, 2 April 2009. 
Third, the jurisdictions from which the definition is said to have been taken have strong democratic culture where the prosecution and the courts have the highest degree of independence and loyalty to rule of law. For example, in relation to the UK anti-terror legislation, Lord Carlile acknowledges that owing to the broadness of the definition of terrorism, non-terrorist conducts including protestors who support women's rights and environmental causes could fall within the terrorism Act 2000 definition. ${ }^{20}$ However, for him such a theoretical possibility is not a problem in a country with strong traditions of democratic accountability as, he believes, that "sensible use of the discretion to prosecute ... would protect individuals from unjustified state interference". ${ }^{21}$

Likewise, the Australian High Court acknowledges that the complexity and nature of the definition of terrorism in the relevant section of the Criminal Code Act 1995 (Cth) makes it capable of catching range of nonterrorist conducts. However, the court held, this quality was not incompatible with the exercise of federal judicial power. ${ }^{22} \mathrm{~A}$ similar position is taken by Justice Rutherford of Canada. While he acknowledges the theoretical possibility that the Anti-Terrorism act 2001 of Canada could be applied to a non-terrorist conduct, he reasons that any conduct that was clearly non-terrorist would be excluded from the definition through judicial interpretation. ${ }^{23}$ This assumption is hardly possible in emerging democracies, like Ethiopia, where such level of reliance on the prosecution and the judiciary is hardly imaginable. ${ }^{24}$

${ }^{20}$ Lord Carlile (2007), Definition of Terrorism A Report by Lord Carlile of Berriew Q.C.; Independent Reviewer of Terrorism Legislation, Cm 7052, para. 34 in Hardy and Williams, supra note 11, p. 118.

21 "Lord Carlile of Berriew Q.C., Report on the Operation in 2005 of the Terrorism Act 2000, 2006, para 30".; Lord Carlile of Berriew Q.C., Independent Reviewer of Terrorism Legislation, The Definition of Terrorism, 2007, Cm. 7052, para 34.; Lord Carlile of Berriew Q.C., Report on the Operation in 2004 of the Terrorism Act 2000, para 27 (U.K.) in Hardy and Williams, supra note 11, p. 118.

${ }^{22}$ Thomas v Mowbray (2007), 233 CLR 307 (Austl.) in Hardy and Williams, supra note $11, \mathrm{p} 133$.

${ }^{23}$ R v Khawaja, [2006] O.J. No. 4245 (Can.) in Hardy and Williams, supra note 11, p. 124

${ }^{24}$ This was the point that Enginer Yilekal, president of the Blue Party, raised during the televised debate on the Ethiopian Anti-terrorism proclamation. Discounting the importance of adapting laws of democracies in and by itself he jokingly asked the government officials to bring the institutions of the democratic countries as well. <https://www.youtube.com/watch?v=Nr76bQEtnlA $>$. 


\subsection{The difficulty of judging the controversy}

Apparently, there is no easy way of judging the dispute pertaining to the broadness of the definition of a terrorist act. That is because of the claimed lack of a definition of terrorism in general and in Security Council Resolution 1373 (hereafter the resolution) in particular. While the resolution is applauded for mobilizing states to take counterterrorism legislative measures (something which could not have been achieved through the treaty process) ${ }^{25}$ it has been subject to several criticisms. ${ }^{26}$ The one major criticism is that it fails to define the term 'terrorist act'. Although the resolution mentions 'terrorism' or 'terrorist act' numerous times, it does not explicitly provide for their meaning.

Roach describes this gap as a 'critical lacunae' in resolution $1373 .{ }^{27}$ Samuel characterizes absence of universal definition of terrorism ${ }^{28}$ in general as the major gap in the rule of law framework of international counterterrorism. ${ }^{29}$ Thus, many have asserted that the Security Council has

${ }^{25}$ Nicholas Rostow (2001-2002), 'Before and After: The Changed UN Response to Terrorism since September $11^{\text {th }}$ Cornell International Law Journal, Vol 35, 475, 481-84.

${ }^{26}$ Resolution 1373 is criticised for circumventing the requirement of consent of States as a conventional law making process by instructing them to adopt and implement anti-terrorism measures. Nigel D. White (2012), 'The United Nations and Counter-Terrorism: Multilateral and Executive Law-Making' in Ana Maria Salinas De Frias, Katja LH Samuel, and Nigel D White (eds.), Counter terrorism International Law and Practice (Oxford University Press) 54, 72; Rostow (20012002), supra note 25, 482; Ben Saul (2005), 'Definition of "Terrorism" in the UN Security Council: 1985-2004,' Chinese Journal of International Law, 141, $161,165$.

${ }^{27}$ Kent Roach (2008), 'Defining Terrorism: the need for a restrained Definition' in Laviolette N, Forcese C (eds.), the Human Rights of Anti-terrorism (Irwin Law, 2008) p. 99.

${ }^{28}$ Two courts, one national another international, have adopted a different view of the definition controversy. The UN Special Tribunal for Lebanon and an Italian court recognize a customary law definition for the crime of terrorism. Ben Saul (2012), 'Civilizing the Exception: Universally Defining Terrorism' in Aniceto Masferrer (ed.), Post 9/11 and the State of Permanent Legal Emergency: Security and Human Rights in Countering Terrorism (2012) 79, 80, 85.

29 Katja LH Samuel (2012), 'The Rule of Law Framework and its Lacunae: Normative, Interpretative, and/or Policy Created?' in Ana Maria Salinas De Frias, Katja LH Samuel, and Nigel D White (eds.), Counter terrorism International Law and Practice (Oxford University Press,) 14, 16-19. 
left the definition of terrorism to individual governments. ${ }^{30}$ Similarly, others observe that the imposition of an obligation on a state to criminalize a 'terrorist' act without providing a definition or guideline means authorizing a state to "define terrorism according to its own history, objectives and concerns" $" 31$ which permits a range of overbroad definitions. Guillaume upholds a similar view and argues that requiring states to take measures against terrorism, without defining it, enables states to make "unilateral interpretations geared towards their own interests." 32

Both sides of the argument on the broadness of the definition of a terrorist act in the Proclamation involve judging its reach according to a standard. If there is no universally accepted definition of a terrorist act, so much so that 'one person's terrorist is another's freedom fighter', ${ }^{33}$ and if justifying the scope of the definition by referencing to definitions in other jurisdictions is not acceptable, what is the right way to evaluate the scope of the definition of a terrorist act under the proclamation? The next section is devoted to investigating what we think is the appropriate standard.

${ }^{30}$ Ben Saul (2006), Defining Terrorism in International Law (Oxford University Press ) 316-17, 320; Rostow, supra note 25, 484; Roach (2008), supra note 27, 98-99; Young (2006), supra note 11, pp. 23, 44.

31 Kent Roach, Michael Hor, Victor V. Ramraj and George Williams (2012), "Introduction" in Kent Roach, Michael Hor, Victor V. Ramraj and George Williams (eds.), Global Anti-Terrorism Law and Policy (Cambridge University Press , $2^{\text {nd }}$ ed.) $1,4$.

32 Gilbert Guillaume (2004), “Terrorism and International Law”, International and Comparative Law Quarterly, Vol. 53, pp. 537, 540.

${ }^{33}$ George P. Fletcher (2006), "The Indefinable Concept of Terrorism", Journal of International Criminal Justice, vol. 4, p. 906. Ved Nanda rightly attributes this cliché to the international community's inability to provide a common definition. Ved Nanda (2001), 'The Role of International Law in Combating Terrorism' Michigan State University-Detroit College of Laws Journal of International Law, Vol. , 10, pp. 603, 604. 


\section{Search for a standard definition}

True, by not expressly defining a terrorist act, the resolution, enforcement of which is one of the justifications for the proclamation, ${ }^{34}$ makes its subject matter unclear. However, it was not meant to give states a blank cheque to fight terrorism according to their own definitions. ${ }^{35}$ By requiring or calling upon states to take the several measures against a terrorist act, it would be logical to assume that the Security Council would not be using the term 'terrorist act' to mean everything or nothing. ${ }^{36}$ It must have been referring to something.$^{37} \mathrm{~A}$ close reading of the resolution, as argued below, suggests what that something is.

Logical consistency requires that terrorist acts, the financing of which states are obliged to criminalize under paragraph 1 of resolution 1373, should not be different from (broader or narrower in scope than) terrorist

${ }^{34}$ Wondwossen D Kassa (2013), 'Examining some of the Raisons deter for the Ethiopian anti-terrorism law', Mizan law Review, Vol 7, No.1, pp. 49-66.

35 Andrea Bianchi (2006), 'Security Council's Anti-terror Resolutions and their Implementation by Member States' Journal of International Criminal Justice, vol 4, 1044-73,1050.

${ }^{36}$ Indeed as argued by Professor Oscar Schachter even lack of a comprehensive definition "does not mean that international terrorism is not identifiable. It has a core meaning that all definitions recognize." Oscar Schachter (1989), "The Extraterritorial Use of Force Against Terrorist Bases', Hous. J. Int'l L. Vol 11, $309,309$.

${ }^{37}$ Other sources confirm this. The Counter Terrorism Committee indicates that its members have a fair idea of the meaning of terrorism under the resolution. CTC Chair (Ambassador Jeremy Greenstock), Presentation to Symposium: Combating International Terrorism: The Contribution of the United Nations, Vienna, 3-4 June 2002 quoted in Saul (2005), supra note 26, 157. Jeremy Greenstock, former British Ambassador to the United Nations and chair of the Committee, stated: "increasingly, questions are being raised about the problem of the definition of a terrorist. Let us be wise and focused about this: terrorism is terrorism. . . . What looks, smells and kills like terrorism is terrorism." John Collins, Terrorism, in Collateral Language: A User's Guide to America's New war 167-68 (John Collins \& Ross Glover eds., 2002) quoted in Alex Schmidt (2004), 'Terrorismthe Definitional Problem', Case Western Reserve Journal of International Law, vol 36, 375. Though some states have expressed their concern about lack of explicit definition in the resolution, others believe that definition is unnecessary as it was defined in a previous General Assembly Resolution. Saul (2005), supra note 26, p. 159. Moreover, Resolution 1373 was passed on the assumption that the meaning of terrorism is known from previous counterterrorism legal instruments. Rostow (2001-2002), supra note 25, 487. 
acts that the International Convention for the Suppression of the Financing of Terrorism (hereafter Suppression of Financing Convention or the Convention) refers to. ${ }^{38}$ Paragraph 3(d) of the resolution calls upon ${ }^{39}$ states to become parties to the Convention. ${ }^{40}$ The Security Council would not have made this call, had it used the phrase 'terrorist acts' (the financing of which it requires states to criminalize, under paragraph 1 of the resolution), differently from its meaning under the Suppression of Financing Convention that it refers to under its paragraph 3(d). If the meaning of terrorist acts, as used under paragraph 1 of the resolution, is different from its meaning under the Convention, states will not be able to comply with both paragraphs 1 and $3(d)$ of the resolution simultaneously. ${ }^{41}$ Where a state, responding to the Security Council's call under paragraph 3(d) of the resolution, ratifies the

${ }^{38}$ Szasz asserts that "the provisions of operative paragraph 1 of Resolution 1373, --are clearly based on the International Convention for the Suppression of the Financing of Terrorism." Paul Szasz (2002), "The Security Council Starts Legislating' American Journal of International Law, Vol. 96, 901, 903. The Counter Terrorism Committee opined that "resolution 1373 should be interpreted in compliance with existing international agreements." UN Information Service (2003), 'Human Rights Committee Briefed on Work of Counter-terrorism Committee' (press release HR/CT/630 27 March 2003)

$<$ http://www.un.org/News/Press/docs/2003/hrct630.doc.htm>.Wainwright,

former expert adviser to the Counter Terrorism Committee, indicates that because resolution 1373 calls upon states to give effect to the relevant counter-terrorism international instruments "the CTC has seen fit to import into its interpretation of the resolution concepts included in those instruments, in particular, the fairly detailed description of terrorism included in the Financing Convention." Jeremy Wainwright 'Some aspects of compliance with UN Security Council Resolution 1373' (2005)

$<$ http://www.opc.gov.au/calc/docs/Loophole_papers/Wainwright_Mar2005.pdf $>$ at 15 June 2014.

39 As noted by Szasz, it is for political reasons that the Council makes participation in the convention optional. Szasz (2002), supra note 38, 903.

${ }^{40}$ The obligations that the resolution imposes on the states under its paragraph 1 are so similar with those imposed under the Suppression of Financing Convention that Bantekas describes Paragraph 3(d) of the resolution which, he thinks, makes a needless call for states to ratify the Convention as 'ironic'. Ilias Bantekas (2003), "The International Law of Terrorist Financing" The American Journal of International Law, Vol. 97, No. 2, pp. 315-333, P. 326

${ }^{41}$ However, it is self-evident that the Security Council would like the States both to implement paragraph 1 and to ratify the Convention in compliance with paragraph 3(d) of the resolution. Thus, the resolution has to be interpreted in such a manner that compliance with both paragraphs at the same time is possible. 
Suppression of Financing Convention, the state undertakes to criminalize financing of terrorist acts as defined under the Convention. ${ }^{42}$ If the meaning of terrorist acts referred to under paragraph 1 of the resolution is different from that provided under the convention, then it will neither practically nor theoretically be possible for the state to comply with both paragraphs of the resolution concurrently. This anomalous consequence would not be the Security Council's intention. The only way to circumvent this anomaly is to interpret 'terrorist acts' as used under paragraph 1 of the resolution and in the Suppression of Financing Convention to refer to the same conduct.

It is reasonable to assume that the Security Council, in mentioning the phrase 'terrorist acts' in the different paragraphs of the resolution, ${ }^{43}$ refers to the same conduct. That is, for example, 'terrorist acts', the financing of which states are instructed to criminalize under paragraph 1 of the resolution would not be different from 'terrorist acts' the commission of which states are required, under paragraph 2(b) of the resolution, to prevent.

Because the meaning of terrorist acts, as used in other paragraphs of the resolution, would not be different from the meaning given to terrorist acts under the resolution's first paragraph (which, as argued above, refers to the meaning of a terrorist act under Article 2 (1) of the Suppression of Financing Convention), it stands to reason that this definition is applicable to terrorist acts that resolution 1373 refers to in all of its different paragraphs. ${ }^{44}$

This argument is supported by the Council's subsequent practice. Although states routinely claim terrorist attacks being made in their territories (based on their own definition of terrorism), the Security Council has never taken every allegation seriously. ${ }^{45}$ The Council has consistently

${ }^{42}$ Szasz, supra note 38 , p. 903.

${ }^{43}$ The resolution has made about forty mentions of terrorism, terrorists or terrorist acts.

${ }^{44}$ It is not uncommon to infer the intention of the Security Council from what it has expressly stated. For example, Szasz argues that in resolution 1373 the Security Council implicitly approves previous General Assembly recommendations. Szasz, supra note 38, p. 903. Similarly, Saul notes that Resolution 1373 implicitly authorized self defence against terrorism. Saul (2005), supra note 26, p. 160 .

45 For the sporadic involvement of the Security Council in domestic terrorism Cases, which arguably do not fall under the Convention's definition, see: Wondwossen Kassa (2013), supra note 34, pp. 60-63. 
confined its involvement to attacks ${ }^{46}$ which are grave enough to be captured by the definition provided under the Suppression of Financing Convention.

The definition of a terrorist act provided under Security Council resolution 1566 of 2004 is another evidence to demonstrate the Security Council's understanding of the term. Under Paragraph 3 of the resolution, the Security Council,

... Recalls that criminal acts, ... committed with the intent to cause death or serious bodily injury, or taking of hostages, with the purpose to provoke a state of terror in the general public or in a group of persons or particular persons, intimidate a population or compel a government or an international organization to do or to abstain from doing any act, which constitute offences within the scope of and as defined in the international conventions and protocols relating to terrorism, are under no circumstances justifiable by considerations of a political, philosophical, ideological, racial, ethnic, religious or other similar nature, ...;

As rightly noted by Hardy and Williams, this definition is "practically indistinguishable" 47 from the definition under the Suppression of Financing Convention. This 'striking' similarity gives credence to the argument that the Council understands the term terrorist act, while passing resolution 1373, to refer to a terrorist act as defined under the Suppression of Financing Convention. ${ }^{48}$ The Security Council espouses the Convention's definition in both resolutions, explicitly in resolution 1566 and tacitly in resolution 1373.

While the definition provided under the Convention is one that is imposed from the Security Council through the resolution, there is another definition that Ethiopia has voluntarily accepted - the definition under the OAU Convention on the Prevention and Combating of Terrorism (hereafter

46 The Council adopted resolutions denouncing bomb attacks (Bali and Kenya in 2002, Bogota and Istanbul in 2003, Madrid in 2004 and London in 2005) and hostage takings (Moscow, 2002).

${ }^{47}$ Hardy and Williams (2011), supra note 11, pp. 77, 93. See Thomas Weigend (2006), "The Universal Terrorist: The International Community Grappling with a Definition", Journal of International Criminal Justice, Vol. 4, p. 920

48 Curtis Ward, Legal Expert for the Security Council's Counter-Terrorism Committee (CTC), invoked a legal instrument(The Ministerial Declaration annexed to Security Council resolution 1456 (2003)) which was passed after resolution 1373 to support his view that the Security Council intended, under resolution 1373, to require states to ensure that their counterterrorism activity is compatible with human rights. UN Information Service, (2003), supra note 38. 
OAU Convention). ${ }^{49}$ Among others, the proclamation is meant to enforce agreements that have been entered into at the United Nations and African level. ${ }^{50}$ A recommendation that the Legal and Administration, and Defence and Security Affairs Standing Committees submitted to the House of Peoples' Representatives indicate that the proclamation is drafted based on international and regional counterterrorism treaties that Ethiopia is a party to. ${ }^{51}$ Thus, the definition under this convention is pertinent to examine the scope of the definition under the Proclamation.

\section{What constitutes a 'terrorist act' under the standard Definitions?}

\subsection{Suppression of Financing Convention}

Paragraph 2(1) of the Suppression of Financing Convention defines a terrorist act as follows.

(a) An act which constitutes an offence within the scope of and as defined in one of the treaties listed in the annex; or

(b) Any other act intended to cause death or serious bodily injury to a civilian, or to any other person not taking an active part in the hostilities in a situation of armed conflict, when the purpose of such act, by its nature or context, is to intimidate a population, or to compel a government or an international organization to do or to abstain from doing any act.

Under paragraph 2(1)(a), a conduct would be regarded as a terrorist act if it falls within one of the nine treaties ${ }^{52}$ listed in the annex to the convention. ${ }^{53}$

49 It was adopted in 1999. Ethiopia ratifies the convention in 2003. Apart from calling, in its paragraph $3(\mathrm{~d})$, for states to become parties to the international treaties relating to countering terrorism Security Council resolution no 1373, in its Paragraph 3 (c), further calls upon states "to cooperate, particularly through bilateral and multilateral arrangements and agreements, to prevent and suppress terrorist attacks and take action against perpetrators of such acts." The OAU Convention has to be seen in this context.

${ }^{50}$ Preamble, Anti-terrorism Proclamation no 652/2009; Wondwossen Kassa (2013), supra note 34 .

${ }_{52}^{51}$ Federal Democratic Republic of Ethiopia, supra note 9, p. 133

52 They are:

1. Convention for the Suppression of Unlawful Seizure of Aircraft, done at The Hague on 16 December 1970. 
Two exceptional instances (where an act that falls within one of these treaties may not be considered as terrorist act for a state party to the Suppression of Financing Convention) are provided under paragraph 2(2) of the Convention. According to sub paragraph 2(2)(a), a state, at the time of becoming a party to the Suppression of Financing Terrorism, has the right to express its reservation that any treaty, which it is not party to, not be deemed to be included in the annex referred to under Paragraph 2(1)(a). If it does not express its reservation, the treaty to which it is not a party will be applicable to that state, by virtue of Paragraph 2(1)(a) of the Convention, for the purpose of criminalizing financing of the act prohibited under the treaty. Similarly, by virtue of sub paragraph 2(2)(b) where a state which had been a party to any of the treaties referred under Article 2(1)(a) of the Convention ceases to be so, it can terminate the applicability of the Suppression of

2. Convention for the Suppression of Unlawful Acts against the Safety of Civil Aviation, done at Montreal on 23 September 1971.

3. Convention on the Prevention and Punishment of Crimes against Internationally Protected Persons, including Diplomatic Agents, adopted by the General Assembly of the United Nations on 14 December 1973.

4. International Convention against the Taking of Hostages, adopted by the General Assembly of the United Nations on 17 December 1979.

5. Convention on the Physical Protection of Nuclear Material, adopted at Vienna on 3 March 1980.

6. Protocol for the Suppression of Unlawful Acts of Violence at Airports Serving International Civil Aviation, supplementary to the Convention for the Suppression of Unlawful Acts against the Safety of Civil Aviation, done at Montreal on 24 February 1988.

7. Convention for the Suppression of Unlawful Acts against the Safety of Maritime Navigation, done at Rome on 10 March 1988.

8. Protocol for the Suppression of Unlawful Acts against the Safety of Fixed Platforms located on the Continental Shelf, done at Rome on 10 March 1988.

9. International Convention for the Suppression of Terrorist Bombings, adopted by the General Assembly of the United Nations on 15 December 1997.

53 At the time when the Suppression of Financing Convention was adopted there were ten counterterrorism instruments: eight conventions and two protocols. The annex (Paragraph 2(1) (a)) to the convention refers to seven of the conventions and to both protocols. The only convention not included in the list is the 1963 Convention on Offences and Certain Other Acts Committed On board Aircraft (Aircraft Convention) which prohibits conduct that do or may affect in-flight safety. 
Financing Convention to the act covered by the treaty which it ceases to be a party to by making a declaration to that effect.

By making such declaration, a state not a party to one of the treaties listed in the Annex to the Financing Convention makes the treaty to be presumed not to be in the list for the purpose of Paragraph 2(1)(a) of the Convention. It is noteworthy that the exclusion of a certain act from sub paragraph 2(1)(a) provides eligibility to be included in the definition provided under sub paragraph ' $b$ '. Though not being included in the treaties listed under article 2(1)(a) is necessary, other elements need to be fulfilled for an act to be regarded as a terrorist act under the definition that sub paragraph 2(1)(b) provides. These elements are discussed below.

Different authors analyse definitions of a terrorist act by taking different elements. ${ }^{54}$ Here two elements of the definition are considered. The first element is what Weigend calls the 'base offence," 55 which refers to the ordinary crime that forms the basis of a terrorist act. The second is what Cassese refers to as 'purpose of the act, ${ }^{, 56}$ which denotes the mental element that distinguishes a terrorist act from ordinary crimes.

\section{Base offence}

The base offence is the underlying crime of a terrorist act which refers to an act "intended to cause death or serious bodily injury". ${ }^{57}$ It has nothing to do with property offences or victimless offences. ${ }^{58}$ As noted by Fletcher, "terrorism is premised on the violent attack on life and security of human beings." ${ }^{59}$ Thus, the first element relates to conduct that is in and by itself "already criminalized" 60 under national criminal law. The act would have been an ordinary crime (as opposed to a terrorist crime) of intentional

${ }^{54}$ For example, Fletcher identifies eight variables of terrorism. Fletcher (2006), supra note 33, pp. 901-911; Cassese approaches the notion of terrorism in terms of its objective and subjective elements in Antonio Cassese (2006), Journal of International Criminal Justice, Vol. 4, 935-958.

${ }_{55}^{55}$ Weigend (2006), supra note 47, p. 929.

${ }_{57}^{56}$ Cassese (2006), supra note 54, p. 938.

${ }^{57}$ There is no restriction on the means of committing the act (it can be a machine gun, knife ...) in so far as it is intended and perhaps reasonably capable of resulting in death or bodily injury. Anthony Aust (2001), "Counter-TerrorismA New Approach: The International Convention for the Suppression of the Financing of Terrorism" Max Planck Institute UNYB, Vol. 5: 11, p. 298.

${ }_{58}^{58}$ Fletcher (2006), supra note 33, pp. 894-911.

${ }^{59}$ Ibid, 894, 901.

${ }^{60}$ Cassese (2006), supra note 54, p. 938. 
homicide or grave bodily injury or an attempt to commit these offences had it not been for the specific purpose accompanying the act.

Young refers to this element of the definition as the "proscribed harm. ${ }^{, 61}$ While Wigenede describes it as the only objective element ${ }^{62}$ of definition of a terrorist act, another scholar describes this element as the actus reus of an international crime of terrorism. ${ }^{63}$ However, in addition to a doing of a certain act, this element has a mens rea dimension/component - the intent to commit homicide/murder and grave bodily injury. The act should be committed intentionally with a view to cause death or serious bodily injury.

\section{Purpose of the act}

Fulfilment of the above element makes a certain conduct to be a candidate to be treated as a terrorist act. ${ }^{64}$ The eligible conduct that fits this category would be a terrorist crime where the actor possesses the 'right' state of mind (intention) ${ }^{65}$ which constitutes the second element under paragraph 2(1)(b) of the Convention. This element relates to the purpose of doing the act. A base offence would be a terrorist act "when the purpose of such act ... is to intimidate a population, or to compel a government or an international organization to do or to abstain from doing any act." The actor must have at least one of the three purposes while doing an act intending to cause death or serious bodily injury on a civilian.

Any act that is intended to cause or has actually caused death or serious bodily injury not accompanied at least by one of these purposes would not constitute a terrorist act. Thus, the purpose for which the doer of the act committed it gives a terrorist nature to what is otherwise an ordinary crime. Cassese refers to this component as the hallmark of a terrorist act. ${ }^{66}$

While the definition is framed in such a manner that it provides three alternative purposes for a terrorist to engage in a terrorist act, the primary goal of a terrorist act is always that of compelling a public or private institution to take a certain course of action. Logically, intimidating a population, though listed as one possible purpose of a terrorist act, can only be used as a means, as opposed to a purpose, for compelling a government or another institution to do or to refrain from doing something. As observed

\footnotetext{
${ }^{61}$ Young (2006), supra note 11, pp. 53-55

${ }^{62}$ Weigend (2006), supra note 47, p. 929.

${ }^{63}$ Antonio Cassese, International Criminal Law, 129.

${ }^{64}$ Weigend (2006), supra note 47, p. 929.

${ }^{65}$ Ibid.

${ }^{66}$ Cassese (2006), supra note 54, 939.
} 
by Fletcher, imposition of fear on the population is a means to reach some political objective. ${ }^{67}$ In a similar fashion Cassese, referring to scaring the population, notes that "it is never an end in itself". ${ }^{68}$

Incorporating intimidating a population as one possible end of a terrorist act makes it easy for law enforcement agencies to get a conviction where the doer's demands in connection with certain acts are unclear. ${ }^{69}$ In such cases, it is enough for the prosecution to show that the actor's immediate purpose is to spread fear among the public. The purpose of the act being inferred from the 'nature' or 'context' of the act, ${ }^{70}$ as opposed to knowledge or intent on the part of the actor that his action will intimidate the population, gives credence to this interpretation.

\subsection{OAU Convention}

Article 1(3)(a) of the OAU Convention defines a terrorist act as:

any act which is a violation of the criminal laws of a State Party and which may endanger the life, physical integrity or freedom of, or cause serious injury or death to, any person, any number or group of persons or causes or may cause damage to public or private property, natural resources, environmental or cultural heritage and is calculated or intended to:

(i) intimidate, put in fear, force, coerce or induce any government, body, institution, the general public or any segment thereof, to do or abstain from doing any act, or to adopt or abandon a particular standpoint, or to act according to certain principles; or

${ }^{67}$ Fletcher (2006), supra note33, p. 902.

${ }^{68}$ Cassese (2006), supra note 54, p. 939

${ }^{69}$ Fletcher (2006), supra note 33, p. 902.

${ }^{70}$ On this Weigend writes that inference from nature or context "means that all that has to be proved is that the actor had mens rea with respect to the base crime (murder, assault or destruction of property) and that that crime was committed in a 'context' that the court deems indicative of terrorism. That is unsatisfactory because the largely increased penalties provided for terrorists can be justified only when the actor is proven to have intended or known that his acts will intimidate the population or interfere with important government functions. Moreover, since the actus reus of terrorist attacks does not differ from 'ordinary' offences, being labeled a terrorist hinges on the presence of a specific subjective element. Leaving determination of that defining element to inference means that the court can without conclusive proof put the terrorist label on one defendant and withhold it from another. Weigend (2006) supra note 47, p. 923 
(ii) disrupt any public service, the delivery of any essential service to the public or to create a public emergency; or

(iii) create general insurrection in a State.

\section{Base Offence}

The definition captures "any act ... which may endanger the life, physical integrity or freedom of, or cause serious injury or death ... or causes or may cause damage to public or private property, natural resources, environmental or cultural heritage ...." Not every act falls within the domain of the base offence of a terrorist act. There are specific protected interests acting against which would make the act potentially a terrorist act. Either the act should endanger or be a transgression against life, physical integrity or liberty of a human person or it should be a wrongdoing against public or private property, natural resources, environmental or cultural heritage. ${ }^{71}$

The definition provision does not require that there be actual or risk of harm/damage or that there be actual endangering of life, physical integrity, or freedom. It simply requires that an act may result in any of the proscribed consequences. The term 'may' is ambiguous. It includes any probability (greater than zero less than 100 percent) that an act would result in the consequences/states of fact. There is no requirement that the actor intends to bring about these consequences or states of fact. Thus, in so far as other elements of the definition are satisfied, almost any act arguably "may" result in the proscribed consequences or states of fact, which deprives any value of incorporating this element.

The definition speaks about the status of the base offence under the criminal law of a state party to the convention. By providing that terrorist act means "any act which is a violation of the criminal laws of a State Party and ...", the definition provision indicates that it does not capture every perpetration of violence against the above mentioned protected interests. It requires that the act, even where it is not accompanied by the purpose elements of the definition of a terrorist act, be criminalized under criminal law of member states as non-terrorist ordinary offence. In other words, it is

${ }^{71}$ Even these acts would not be considered as a terrorist act if the situation in which the acts are committed falls under article 3 of the Convention. According to this provision, "the struggle waged by peoples in accordance with the principles of international law for their liberation or self-determination, including armed struggle against colonialism, occupation, aggression and domination by foreign forces shall not be considered as terrorist acts." 
not any act that causes death, bodily injury, damage to property and other consequences or states of fact that falls within the domain of acts which are potentially terrorist acts. An act which may cause any of the proscribed harms or states of fact would be eligible to the category of terrorist acts to the extent it is criminalized in a domestic criminal law. ${ }^{72}$

\section{Purpose of the Act}

The definition provides for a list of three possible purposes that the actor might intend his act to serve. Each consists of a broad coverage of purposes. The first purpose is to "intimidate, put in fear, force, coerce or induce any government, body, institution, the general public or any segment thereof, to do or abstain from doing any act, or to adopt or abandon a particular standpoint, or to act according to certain principles." This purpose has four component elements. First, it relates to exerting certain pressure and/to terrorize--intimidating, putting in fear, forcing, coercing or inducing. Second, this pressure is exerted on "any government, body, institution, the general public or any segment thereof." Third, the actor may demand any of those against whom he exercises pressure. This is as opposed to the definition under the Suppression of Financing Convention where though the pressure might be directed at the public or its part and the government, it is only the government that the actor demands to do or not to do something. ${ }^{73}$ Fourth, the demand might have a variety of forms. It may relate to demanding any of the aforementioned "to do or abstain from doing any act, or to adopt or abandon a particular standpoint, or to act according to certain principles." Unless the latter two are argued to be subsumed in "to do or to refrain from doing," the phrase incorporated in the Suppression of Financing Convention, in which case the definition would be criticised for being redundant, the African definition is broader than the UN definition.

The second purpose of committing any of the base offences relates to disrupting any public service, the delivery of any essential service to the public or to creating a public emergency. The third possible purpose of doing any of the acts to be a terrorist act is the creation of general

${ }^{72}$ Because national criminal laws relating to protection of life, security and freedom of a person and to property are not likely to be identical including this requirement opens a room for variety of definitions of terrorist act across the continent. This definition recognizes a possibility where a terrorist act for one state is not so for another state.

${ }^{73}$ Christian Walter (2003), Defining Terrorism in National and International law, p.13. Retrieved from:

$<$ https://www.unodc.org/tldb/bibliography/Biblio_Terr_Def_Walter_2003.pdf $>$ 
insurrection in a State. These two purposes envisioned by the definition provision are not included in the definition under the Suppression of Financing Convention. Because the three possible purposes of committing an act are provided alternatively, it seems that an act can be a terrorist act without being intended to compel government or public or part of it to do an act or refrain from doing an act. To that extent, the definition lacks what is considered as the core feature/characteristic of a terrorist act.

\section{Definition of a terrorist act under the Proclamation}

Article 3 of Proclamation No. 652/2009 titled 'terrorist acts ${ }^{\text {}}{ }^{74}$ provides:

Whosoever or a group intending to advance a political, religious or ideological cause by coercing the government, intimidating the public or section of the public, or destabilizing or destroying the fundamental political, constitutional or, economic or social institutions of the country:

1) causes a person's death or serious bodily injury;

2) creates serious risk to the safety or health of the public or section of the public;

3) commits kidnapping or hostage taking;

4) causes serious damage to property;

5) causes damage to natural resource, environment, historical or cultural heritages;

6) endangers, seizes or puts under control, causes serious interference or disruption of any public service; or

7) threatens to commit any of the acts stipulated under sub-articles (1) to (6) of this Article;

is punishable with rigorous imprisonment from 15 years to life or with death.

\section{Base offence}

The definition provides for list of seven 'base offences' the commission of which would constitute a terrorist act when accompanied by subjective elements incorporated in the introductory part of the provision. While some of the base offences require that a certain result (harm) be achieved, others do not. For the latter, creating danger or risk of harm suffices.

74 Though Article 3 of the Anti-terrorism proclamation is titled 'terrorist acts', it simply prescribes the punishment attached to the acts which are listed thereunder. However, we assume that the provision is intended to define a terrorist act as an act which satisfies the conditions provided thereunder. 
To the first belong causing a person's death or bodily injury, serious damage to property, damage ${ }^{75}$ to natural resources, environment, historical or cultural heritages, causing serious interference or disruption of any public services and kidnapping or taking of hostages. Two of the offences on the list belong to the second category: creating serious risk to safety or health of the public or section of the public and endangering, seizing or putting under control of any public services. The seventh on the list criminalizes, as a terrorist act, a mere threat to commit any of the other six.

\section{Purpose of the act}

The purpose for which the doer did commit an act makes what is otherwise an ordinary crime a terrorist crime. ${ }^{76}$ As noted by Thomas Weigend, "the offender's 'specific' intent accompanying his overt act is what sets a terroristic murder, bombing or assault apart from an 'ordinary' crime of the same kind." 77

The definition requires that the base offence be committed with intent to serve one of the several purposes for it to be a terrorist act. Three possible purposes are envisaged. These are coercing government in Ethiopia (at state or federal level) or foreign government or international organization; intimidating the public or section of the public; or destabilizing or destroying the fundamental political, constitutional, economic or social institutions of Ethiopia. With regard to the level of pressure on the government, it is required that the actor intends to 'influence' the government. It is noteworthy that the Amharic version provides for 'coercion' which is a higher and narrower form of pressure. A draft of the law, dated January 2009, used the words "coercing or intimidating" in place of "influence."

As Human Rights Watch observes, "it is not clear if the change represents a government attempt to make the definition of terrorism broader $\ldots$, or whether this is primarily a translation issue". ${ }^{79} \mathrm{Be}$ the reason for change of words as it may, for interpretation purpose the Amharic version of

\footnotetext{
${ }^{75}$ The Amharic version requires that the damage be serious as in the case of damage to property.

${ }^{76}$ Young argues "intimidation or coercion should be regarded as a necessary element of terrorism as a legal concept at international law." Young (2006), supra note 11, p. 57.

${ }_{77}^{77}$ Weigend (2006), supra note 47, p. 923.

${ }^{78}$ Human Rights Watch (2009), supra note 2, p. 3.

${ }^{79}$ Ibid.
} 
legislation prevails over the English. ${ }^{80}$ Thus, courts would apply the Amharic version that retains the word which was used at the draft stage of the legislation thereby avoiding the possible expansive consequence of the term introduced in the final English version of the definition provision.

The proclamation's definition incorporates the phrase "... coercing the government, intimidating the public or section of the public, or...", and because of the wording of the definition, it is not clear if these are provided as purposes of a terrorist act. Adding to the confusion, possible motives of the actor (advancing a political, religious or ideological cause) are incorporated as elements of the definition of a terrorist act. In principle, motive is irrelevant in establishing criminal responsibility. ${ }^{81}$

Owing to phrasing, the introductory part of the definition which states "whosoever ...intending to advance a political, religious or ideological cause by coercing the government, intimidating the public or section of the public, or..." suggests that what are normally considered as purposes of a terrorist act are stated as means of achieving the motives.

\section{Appraisal of the definition vis-à-vis the standard definitions}

This Section examines the proclamation's definition of a terrorist act in light of the definitions provided under the international and regional legal instruments. It has been argued earlier that the resolution points to a definition of terrorist act that states ought to follow while passing their own counterterrorism legislation. As noted above, by ratifying the OAU Convention, Ethiopia has voluntarily accepted the definition provided thereunder as a guiding definition.

${ }^{80}$ Federal Negarit Gazeta Establishment, 1995, Art. 2(4), Proc. No. 3, Neg. Gaz. Year 1, No.3

81 Fletcher, G.P. (2000), Rethinking Criminal Law, (Oxford: Oxford University press), p. 452; Kent Roach (2001), 'The New Terrorism Offences and the Criminal Law' in: Ronald J Daniels, Patrick Macklem and Kent Roach (eds), The Security of Freedom: Essays on Canada's Antiterrorism Bill (University of Toronto Press, Toronto) p. 156; Kent Roach (2007), 'The Case for Defining Terrorism With Restraint and Without Reference to Political or Religious Motive' in: Andrew Lynch et al (eds) (2007), Law and Liberty in the War on Terror (Federation Press, Sydney), p. 43. 
Because the proclamation has been enacted with a view, inter alia, to enforce these regional and international legal instruments, ${ }^{82}$ examining the proclamation's definition of a terrorist act vis-a-vis the definitions in these instruments would mean judging it by its own standard.

\subsection{Elements where the Proclamation's definition reveals broadness}

\section{Base offence}

This part of the definition of a terrorist act under the Proclamation deviates from the international definition in two major points. First, it encompasses conduct not incorporated in the latter. Among the list of seven acts under Article 3 of the Proclamation only the first, namely, an act that "causes a person's death or serious bodily injury" is captured by the meaning of a terrorist act under Paragraph 2(1)(b) of the Suppression of Financing Convention. Others are not envisaged by the definition of a terrorist act under the international instrument. ${ }^{83}$ UN Special Rapporteur on Human Rights and Counterterrorism holds the view that the concept of terrorism

82 Preamble part of the Proclamation; Federal Democratic Republic of Ethiopia (2008/2009), supra note 9, p. 133.

83 This assertion on the proclamation's deviation from the definition under the Suppression of Financing Convention is subject to a proviso. The fact that an act is not covered by the general definition of a terrorist act under Article 2(1) (b) of the Suppression of Financing Convention does not necessarily exclude it from being a terrorist act under the Convention. By virtue of its Article 2(1) (a), the Convention treats acts proscribed by the treaties listed on its Annex as a terrorist act without requiring that the act relates to causing damage to one's life or body. Thus, to the extent the other acts listed in the definition of the anti-terrorism proclamation fall within the scope of the specific anti-terrorism treaties, ${ }^{83}$ the acts would still be within the scope of the Convention's definition. For example, under Diplomatic Agents Convention (1973) kidnapping of an internationally protected person, in and by itself, constitutes a terrorist act. That means, while incorporating kidnapping as a base offence of terrorist act under the antiterrorism proclamation appears to go beyond the scope of definition of a terrorist act under the Suppression of Financing Convention, to the extent it is applied for an internationally protected person (as defined in the Diplomatic Agents Convention) it is compatible with the Convention's definition. Similarly, if a hostage taking is accompanied by "threat to kill, to injure or to continue to detain another person," it would fall under the Hostages Convention (1979) making its inclusion in the definition of a terrorist act under the Anti-terrorism proclamation harmonious with the definition under Suppression of Financing Convention. 
should be limited to acts committed with the intention of causing death or serious bodily injury, Kidnapping and the taking of hostages, and not property crimes, 84

Commenting on this divergence of the Proclamation's definition, Amnesty International indicates:

This definition of terrorism includes acts that do not involve violence or injury to people, such as property crimes and disruption of public services. The United Nations special rapporteur on counterterrorism and human rights has stated that the concept of terrorism should be limited to acts committed with the intention of causing death or serious bodily injury, or the taking of hostages, and should not include property crimes. $^{85}$

Secondly, under the Convention's definition an act, to be a terrorist act, must have been intended to cause death or bodily injury. The definition under the Anti-terrorism proclamation does not require that the act be intended by the actor to cause the harm or risk listed thereunder. Nor does the definition call for the harm or risk results from negligence. In so far as one's act results in death, bodily injury or any of the consequences listed in the definition, irrespective of mens rea of the actor relating to the consequence, it will constitute a base offence of a terrorist act under the antiterrorism proclamation. It follows that if other elements of the definition are fulfilled, an act which causes death, bodily injury, or any other harm or danger of harm listed thereunder would be treated as a terrorist act even if the actor did not intend the act to bring about such result.

While the proclamation's definition and the OAU definition share most of the base offences ${ }^{86}$ of a terrorist act, a close look at the definitions reveals the following differences. Under both definitions, any act that causes death or bodily injury would constitute a terrorist act if accompanied by other elements. However, while the Ethiopian definition requires actual death or bodily injury, the OAU definition makes an act "which may endanger" one's "life, physical integrity" as well a potentially terrorist act. Similarly unlike the Ethiopian definition which requires actual kidnapping or taking of

${ }^{84}$ Human rights Watch, Ethiopia: Amend draft law proposed counterterrorism legislation violates human rights. Retrieved from:

$<$ http://www.hrw.org/news/2009/06/30/ethiopia-amend-draft-terror-law>.

${ }^{85}$ Human Rights Watch (2009), supra note 2.

${ }^{86}$ Causing serious injury or death; causing damage to property; and causing damage to natural resources, environmental and cultural heritages constitute base offences under both definitions. 
hostages, an act that "may endanger freedom" suffices to constitute a base offence of a terrorist act under the OAU Convention. While both the OAU Convention and the anti-terrorism proclamation declare damage to property as one of the base offences, only the latter requires that the damage be 'serious'. There are acts which are declared as potentially terrorist under the definition of the Proclamation but not under the OAU definition. These are an act that causes damage on historical heritage, and an act that "creates serious risk to the safety or health of the public or section of the public."

The failure of Article 3 of the Proclamation to require criminal fault relating to the act that causes any of the harms or risks listed thereunder is a major gap making it broader than Article 1(3) of the OAU convention in relation to the base offences that the two definitions share. The latter, inter alia, requires that the act be criminalized under criminal law of state parties, which ensures the fulfilment of the mens rea element. The definition under Article 3 of the Proclamation does not require that the conduct be independently criminalized under the Criminal Code or in any other criminal law of Ethiopia. Nor does it require that there be criminal fault in causing the harm or risk of harm.

Thus, if the other elements of a terrorist act provided in the introductory part $^{87}$ of Article 3 are fulfilled, the person who 'causes' any of the listed harms thereunder, be it accidentally or negligently, will be treated as a terrorist person. That is, in so far as one's intention "to advance a political, religious or ideological cause" through "coercing the government, intimidating the public or section of the public, or destabilizing or destroying the fundamental political, constitutional or, economic or social institutions of the country" is known and can be proved, then he will automatically be considered as a terrorist person if his act causes any of the harms or risks of harm listed thereunder, with no need to prove that the act was intended or committed negligently. The OAU Convention does not allow that.

\section{Purpose of the Act}

For a certain act to be a terrorist act under the Suppression of Financing Convention, its purpose should be "to intimidate a population, or to compel a government or an international organization to do or to abstain from doing any act." Range of purposes of committing the base offence of a terrorist act is provided in the Proclamation's definition. These are "coercing the government, intimidating the public or section of the public, or destabilizing

\footnotetext{
${ }^{87}$ As discussed below the intention requirement provided in the introductory
} statement applies to other elements of the definition. 
or destroying the fundamental political, constitutional or, economic or social institutions of the country." While broadly speaking the two definitions refer to similar purposes, there are important differences. Coercing an international organization to do or to refrain from doing a certain act, one of the purposes under the Convention's definition, is not included among the purposes under the Proclamation's definition. On the other hand "destabilizing or destroying the fundamental political, constitutional or, economic or social institutions of the country," which constitutes one possible purpose for a terrorist act under the proclamation, is not covered by the Convention's definition.

Under the Convention's definition, the coercion against the government is to force it to take some steps - to do or to refrain from doing a certain act(s). Apart from requiring that there be coercion, the anti-terrorism proclamation does not explicitly indicate that the actor demands the government to do or to refrain from doing something. Any sort of coercion (with no need to show that the coercer demands the government to do or to refrain from doing a specified act) suffices to satisfy this element of the definition. On the other hand, while the requirement that the actor be motivated by religious, political or ideological causes is incorporated under the Ethiopian definition, it is not relevant under the international definition.

The specific treaties listed in the Annex to the Suppression of Financing Convention do not require that an act they respectively proscribe be intended to influence the government or intimidate the public for it to be considered as a terrorist act. Because the purpose element of the definition under Article 3 of the anti-terrorism proclamation is applicable to all eligible base offences (including those covered by specific treaties), the Proclamation provides for a narrower instance where these acts would be treated as terrorist acts. Thus, an act which may not be treated as a terrorist act under the proclamation because it is not accompanied by the purpose element of the definition might be a terrorist act under the Suppression of Financing Convention upon satisfying any one of the treaties listed in the Annex to the Convention.

While the definition under the Proclamation does not provide what is being demanded and from whom, the purpose of committing a terrorist act under the OAU Convention is to "intimidate, put in fear, force, coerce or induce any government, body, institution, the general public or any segment thereof." And the demand is to be made against any of them "to do or abstain from doing any act, or to adopt or abandon a particular standpoint, or to act according to certain principles."

Disrupting public service, the delivery of any essential service to the public, which is treated as a base offence under the proclamation, is treated 
as one possible purpose of committing the base offence under the OAU convention definition. As a consequence, under the OAU Convention but not under the Proclamation, causing property damage or any of the base offences provided thereunder with a view to "disrupt any public service or the delivery of any essential service to the public" would constitute a terrorist act with no need to establish intimidation, putting in fear, forcing, coercing or inducing any government, body, institution, the general public or any segment thereof.

While the definition under the OAU Convention envisions different level of pressure (forcing, coercion or inducement) as constituting the purpose of committing the base offence, the Proclamation's definition captures only the extreme influence (coercion) on the government.

\subsection{Elements where the Proclamation's definition reveals narrowness}

\section{Requirement of actor's motive ${ }^{88}$}

The proclamation's definition, unlike the regional and international definitions, requires that the base offence and purpose of the act be accompanied by specific motive. It is where "whosoever or a group intending to advance a political, religious or ideological cause ..." commits the proscribed act with the proscribed purpose that a terrorist act is said to be committed under the Proclamation's definition. A document that provides a brief explanation about the draft anti-terrorism proclamation makes reference to the motive of the doer of a terrorist act as one of the factors that makes a terrorist act different from other ordinary crimes. ${ }^{89}$ However, under international law, what makes one a terrorist is not the motive for doing the

${ }^{88}$ For a discussion on the background of how the requirement of motive was made element of definitions in some jurisdictions see: Douglas (2010), supra note 14, Must terrorists act for a cause? The motivational requirement in definitions of terrorism in the United Kingdom, Canada, New Zealand and Australia, Commonwealth Law Bulletin, 36:2, 295-312, DOI: 10.1080/03050718.2010.481400

89 Federal Democratic Republic of Ethiopia (2008/2009), supranote9, p.71. For more arguments in support of the motive requirement see: Douglas (2010), supra note 14, p. 307- 311; Ben Saul (2007), 'The Curious Element of Motive in Definitions of Terrorism: Essential Ingredient or Criminalising Thought' in: Andrew Lynch et al (eds) (2007), Law and Liberty in the War on Terror (Federation Press, Sydney ), 29-30; Saul (2006), supra note 30, pp. 38-41 
act but the purpose of doing the act. ${ }^{90}$ John Dugard went as far as arguing that "an ideal definition of terrorism "should expressly state that motive is irrelevant in determining whether an act of terrorism has been committed". ${ }^{91}$ As argued by some, the inclusion of this element would unduly narrow the definition and cause unnecessary hurdle for the prosecution to get terrorists convicted. ${ }^{92}$

Objecting incorporation of this requirement under Australian law "the Commonwealth DPP and the Attorney General's Department argued before the Security Legislation Review Committee that it was 'not in the public interest for a person to avoid criminal liability by showing that his or her acts were motivated by something other than politics, religion or ideology". 93

\section{Failure to protect the public in a foreign country}

Another area where the definition has a narrow scope of application relates to the public that it protects. There is state obligation under international law to cooperate with other governments in counterterrorism. This suggests that a terrorist act, no matter where it is committed or/and against whom it is committed, should be proscribed by every state. However, the definition provision of the anti-terrorism proclamation restricts scope of application of the law to the protection of the Ethiopian public. Because the term 'government' is defined as "the federal or a state government or a government body or a foreign government or an international organization", it is not confined to protect the state and federal governments of Ethiopia.

${ }^{90}$ Cassese, supra note 54, pp. 940ff. Duchemann attributes the absence of the motive element in international conventions to the need to reach consensus on the definitions. Adam Duchemann, Defining Terrorism in International Law so as to Foster the Protection of Human Rights, retrieved from:

$<$ https://www.academia.edu/2912017/Defining_Terrorism_in_International_Law so_as_to_Foster_the_Protection_of_Human_Rights $>$.

91 John Dugard (1974), "International Terrorism: Problems of Definition", RIIA, Vol. 50, no 1, p. 80.

92 Commonwealth Secretariat, Draft Model Legislation on Measures to Combat terrorism 42 (2002); Cassese, supra note 54, p. 941. For more on criticism of the motive requirement see: Douglas (2010), Supra note 14, 301-307. DOI: $10.1080 / 03050718.2010 .481400$

${ }^{93}$ Nicola McGarity (2010), "Testing" our counterterrorism laws: the prosecution of individuals for terrorism offences in Australia 34 Crim LJ , 92-127, p.114, note 182. 
The definition captures an act committed to coerce foreign governments. However, it does not capture acts intended to intimidate a public or part of a public of another state ${ }^{94}$ and acts intended to destabilize or destroy the fundamental political, constitutional or economic or social institutions of foreign country as terrorist. While the definitions under the Suppression of Financing Convention and the OAU Convention capture intimidation or putting in fear of any state's population or a part thereof, the Proclamation's definition applies only to Ethiopian population or a segment thereof. This approach would have an unacceptable consequence. For example, committing an act resulting in any of the harms or risks listed under the definition would not make one a terrorist if $s / h e$ intends to intimidate the public in a foreign country contrary to the international and regional definitions.

\section{What do the discrepancies mean for the validity of the definition under the Proclamation?}

We note, in the previous section, that the definition of a terrorist act under the proclamation deviates from the regional and international definitions. While relating to some aspects the definition in the proclamation is wider in scope, on other aspects it is narrower. This section deals with the effect of these discrepancies on the validity of the proclamation's definition, which turns on what the resolution and the OAU Convention require of states in relation to criminalization of a terrorist act.

To this end, we need to examine whether the instruments instruct states to criminalize certain conduct, without meanwhile requiring them not to criminalize other conduct, as a terrorist act, or whether they require states to criminalize certain conduct, but not others, as a terrorist act. In the former scenario, the states would comply with the instruments by criminalizing every conduct that falls within the respective meaning of a terrorist act in the two instruments. States are free to adopt a definition that captures conduct beyond what the instruments treated as a terrorist act. It follows that a domestic definition would be in conflict with international or regional definition only where the domestic definition fails to capture, but not where it goes beyond, a conduct criminalized by the latter.

${ }^{94}$ Unlike Article 2(1) (b) of the Suppression of Financing Convention which is phrased as "---is to intimidate a population" Article 3 of the proclamation is formulated as "---intimidating the general public or section of the public ..." which refers only to the Ethiopian public or section of the Ethiopian public. 
If, on the other hand, the instruments require states to criminalize as terrorist act only a conduct that their respective definition captures (no less no more), states will be obliged to confine their definition of a terrorist act to the definitions in the regional and international instruments. Under this interpretation, for a state to comply with the instruments, its definition of a terrorist act should match that provided under the respective definitions of the two instruments. ${ }^{95}$ It follows that state definition would contravene with the respective definitions of the two instruments not only where it fails to include, but also where it goes beyond, a conduct that the latter captures.

Scholars who criticise the Security Council for not including a definition of a terrorist act under its resolution $1373^{96}$ would support the second interpretation. They are of the view that had there been a definition under resolution no 1373, states would have been required to adopt that definition. They attribute the proliferation of divergent definitions of a terrorist act across the globe to the Security Council's alleged failure to attribute meaning to a terrorist act in its resolution $1373^{97}$ and blame ${ }^{98}$ the Council for this. Amnesty International shares this view. ${ }^{99}$

There is reaction of scholars to what is deemed as a definition of a terrorist act under Security Council resolution 1566 (2004) as being a late response $^{100}$ to rectify the failure of resolution 1373 to define a terrorist act. According to these scholars, the delay has resulted in broad and divergent domestic definitions. The criticism is that the definition came after many of the states had already adopted their own definition of a terrorist act since 2001, following the instruction under resolution 1373. This criticism is based on the premise that had that definition been incorporated in resolution 1373 , it would have been a mandatory definition to be adopted by states

${ }^{95}$ Because the definitions provided under the OAU Convention and the Suppression of Financing Convention are different in scope this interpretation would make it practically impossible for a state party to the OAU convention to adopt a definition of a terrorist act that would satisfy both definitions.

${ }^{96}$ Roach (2008), supra note 27; Saul (2005), supra note 26.

${ }^{97}$ Roach (2008), supra note 27, pp. 97, 98; Beth Elise Whitaker (2007), 'Exporting the Patriot Act? Democracy and the 'war on terror' in the Third world' 28 (5) Third World Quarterly, Vol 28, No. 5, p. 1017.

${ }^{98}$ Roach (2008), supra note 27, pp. 98-99

${ }^{99}$ Noting that 'the terms 'terrorists' and 'terrorist acts' in resolution 1373 are open to widely differing interpretations,' Amnesty International expresses its fear that this may facilitate rights violations. Amnesty International (2011), Statement on the Implementation of SC Res 1373, 1 October 2001.

${ }^{100}$ Saul (2005), supra note 26, p.165; Roach (2008), supra note 27, p. 99. 
thereby preventing the diversified and broad definitions of a terrorist act in domestic legislation.

On the other hand, Reuen Young supports the first view. For Young, while it is crucial for states to harmonize domestic anti-terrorism laws with international law, the latter is "only one of the relevant considerations taken into account in the anti-terrorism law-making process." In view of the international nature of counterterrorism it is logical that states draw on "international law's jurisprudence concerning the definition of terrorism," and states, according to Young, are "entitled to proscribe conduct beyond that which they are required to proscribe pursuant to international obligations". ${ }^{101}$ In the following paragraph which summarizes the gist of his argument, Young indicates the right of the states to define a terrorist act as something that is derived from their sovereignty. ${ }^{102}$

The international definition should be regarded as a minimum; states' definitions should be assessed against this standard. States are entitled to proscribe further conduct ... . To think otherwise would wrongly construe international law, rather than the state, as the source of sovereignty.

A close reading of relevant provisions of the resolution and the OAU Convention confirms Young's view. The instruments simply instruct states to criminalize terrorist act and other related conduct and punish those who are involved in such conduct. According to Paragraph 2(b) of the resolution, "states shall take necessary steps to prevent the commission of a terrorist act" of which one is criminalization and prosecution. This duty is explicitly stated under Paragraph 2(c) of the resolution which requires states to "ensure that, ... terrorist acts are established as serious criminal offences in domestic laws and regulations and that the punishment duly reflects the seriousness of such terrorist acts." In connection with prosecution, the same paragraph instructs states to "ensure that any person who participates in the financing, planning, preparation or perpetration of terrorist acts or in supporting terrorist acts is brought to justice." Similarly, Article 2(a) of the OAU Convention provides for obligation of state parties to "... establish criminal offences for terrorist acts as defined in this Convention and make such acts punishable by appropriate penalties that take into account the grave nature of such offences."

\footnotetext{
${ }^{101}$ Young (2006), supra note 11, pp. 99-100.

102 Ibid, p. 100.
} 
Owing to the transnational nature of terrorism, both the OAU Convention and the resolution, in their preambular ${ }^{103}$ and operative paragraphs, ${ }^{104}$ make reference to cooperation among states in countering terrorism. Even though these paragraphs suggest that states ought to adopt a definition that would make cooperation possible, ${ }^{105}$ it does not necessarily mean that states need to define a terrorist act in exactly the same way as provided in the definitions of the regional and international instruments. It is only to the extent that a state anti-terror law relates to terrorist act that falls within the definitions of the regional and international instruments that another state is called upon to cooperate for the enforcement of the law.

The provisions relating to cooperation should not be construed as calling for one state to cooperate with another in the enforcement of the latter's antiterrorism law in its full extent. Because provisions relating to cooperation in counterterrorism are applicable in relation to terrorist acts as understood in the respective definitions of the two instruments, defining a terrorist act in such a manner that it encompasses a conduct that the respective definitions

103 The seventh and eighth paragraphs of the resolution respectively states:

"Calling on States to work together urgently to prevent and suppress terrorist acts, including through increased cooperation and full implementation of the relevant international conventions relating to terrorism," and

"Recognizing the need for States to complement international cooperation by taking additional measures to prevent and suppress, in their territories through all lawful means, the financing and preparation of any acts of terrorism."

The sixth paragraph of the OAU Convention provides:

desirous of strengthening cooperation among Member States in order to forestall and combat terrorism

104 Paragraph 2(f) of the resolution requires that states "[a]fford one another the greatest measure of assistance in connection with criminal investigations or criminal proceedings relating to the financing or support of terrorist acts, including assistance in obtaining evidence in their possession necessary for the proceedings"; Paragraph 3 (a-e) of the resolution call for states to engage in different joint activities with a view to fight terrorism. Article 5 of the OAU Convention provides for range of areas where state parties need to cooperate in countering terrorism.

105 Paragraphs relating to cooperation among states in counterterrorism would be effectively implemented if states define a terrorist act consistently. Thus, state compliance with the definition provided under the respective definitions of the OAU Convention and the resolution would facilitate consistency among domestic definitions which in turn facilitates the cooperation in countering terrorism. 
of the two instruments captures plus some other conduct would not have impact on the enforcement of these provisions. These provisions simply reinforce the argument that state definitions should be broad enough to encompass every act that falls within the scope of the definitions of the OAU convention and the resolution. Thus, the provisions, the enforcement of which envisages communality among domestic definitions of a terrorist act, should not lead one to the conclusion that states are not allowed to define a terrorist act differently from the definitions under the regional and international instruments.

Both the regional and international legal instruments require states to criminalize certain conduct as terrorist act with no explicit or tacit prohibition of states from adopting broader definition of a terrorist act. Thus, state definition's being broader than the regional or international definition does not make it incompatible with the latter. The definition of a terrorist act under the Anti-terrorism proclamation, by incorporating acts which are not within the scope of the base offence of the international and regional meaning of a terrorist act, is broader than the latter. But that does not make it in contravention of these instruments. However, a definition that is broad so as to embrace conduct other than that envisioned under the Suppression of Financing Convention and the OAU Convention may have a negative consequence on human rights. ${ }^{106}$

A state definition will be incompatible with the international and regional definition to the extent it fails to capture a conduct which falls within the scope of the international and regional definitions respectively. The definition of a terrorist act under the proclamation, by requiring motive as an additional element and by excluding a crime committed against a public in a foreign state, makes it narrower than the meaning attributed to a terrorist act under resolution 1373 and the OAU convention.

\section{Conclusion}

While there has been live controversy surrounding the scope of definition of a terrorist act under the Ethiopian anti-terrorism law, both sides of the debate do not seem to ground their arguments on relevant standard. One cannot claim that the definition of a terrorist act under the Anti-terrorism

106 Laetitia Bader, Human Rights Watch's researcher on Ethiopia, criticises the definition as being broad so as to include peaceful protests and lawful speech. IRIN (2012), Briefing: Ethiopia's ONLF rebellion. Retrieved from:

$<$ http://www.irinnews.org/report/96658/briefing-ethiopia-s-onlf-rebellion>. 
Proclamation is wide or narrow without a standard. This article proposes the definitions provided under the OAU Convention on the Prevention and Combating of Terrorism and the International Convention for the Suppression of the Financing of Terrorism, which has been endorsed by the Security Council resolution 1373, to be the appropriate standards in light of which the scope of the Proclamation's definition has to be evaluated. Examination of the Proclamation's definition in light of these standard definitions reveals that while in respect to some elements the definition in the proclamation is broader, in others it is narrower.

Although broadness does not, per se, make the definition in the proclamation incompatible with the standard definitions, it might ultimately render the definition to be constitutionally, and from human rights perspective, suspicious. Because the regional and international instruments instruct states to criminalize conduct that falls within the scope of their respective definitions, narrowness of the Proclamation's definition, on the other hand, makes the definition incompatible with the international and regional definitions. Its strict application would mean non-prosecution or, in the event of prosecution, acquittal of persons who would be treated as terrorist under regional and international law. The definition, by leaving some terrorist acts unaddressed, makes Ethiopia fail to discharge its counterterrorism responsibility. Moreover, this defeats one of the proclamation's declared purpose, i.e., enforcement of the regional and international counterterrorism instruments. 